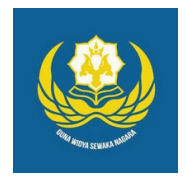

Jurnal Analogi Hukum

Journal Homepage: https://ejournal.warmadewa.ac.id/index.php/analogihukum

\title{
Pelaksanaan Perlindungan Hukum Terhadap Perempuan Sebagai Saksi Korban Kekerasan Dalam Rumah Tangga
}

\author{
Andrie Eka Putra*, Anak Agung Sagung Laksmi Dewi dan Ni Made Sukaryati Karma
}

Fakultas Hukum, Universitas Warmadewa, Denpasar, Bali-Indonesia

*putraa.andre99@gmail.com

How To Cite:

Putra, A. E., Dewi, A. A. S. L., \& Karma, N. M. S. (2021). Pelaksanaan Perlindungan Hukum Terhadap Perempuan Sebagai Saksi Korban Kekerasan Dalam Rumah Tangga. Jurnal Analogi Hukum. 3 (2). 221-224. Doi: https://doi.org/10.22225/ah.3.2.2021.221-224

\begin{abstract}
Violence against women in general is a problem experienced by many women, especially if the violence occurs in the household, because the problem is still considered taboo and is still considered a family problem that is resolved kinship. This shows that there are still many female victims of domestic violence that keep their mouths shut and keep these problems tightly. The formulations of the problems raised are 1) What are the factors causing violence in the household, 2) How is the implementation of the law against women as witnesses of domestic violence in Denpasar District Court. The type of research used is the type of empirical research. The results of the discussion of this study are the factors that cause domestic violence to occur due to the lack of communication between husband and wife in the family which is a determinant of family harmony and the implementation of legal protection for women as witnesses of victims of domestic violence in Denpasar District Court. run effectively as stipulated in the legal provisions. So that law enforcement officers can resolve cases of domestic violence properly so that they can provide protection to women as victims of domestic violence.
\end{abstract}

Keywords: Protection of Rules; Women; Domestic Violence.

\begin{abstract}
Abstrak-Perbuatan kebengisan kepada wanita menurut umum ialah kejadian yang banyak di alami oleh banyak wanita, Bahkan jika perbuatan kebengisan tersebut berlaku pada rumah tangga, lantaran kejadian tersebut masih dianggap tabu dan masih dianggap seperti kejadian keluarga yang di selesaikan menurut kekeluargaan. Hal ini menampakkan masih melimpah korban wanita kebingasan pada tempat tinggal menutup perkataan dan menyimpan masalah tadi rapat-rapat. Rumusan masalah yang di angkat yakni 1) Apa saja yang menjadi faktor-faktor pembawa terjadinya KDRT, 2) Bagaimana pelaksanaan kasus kepada perempuan sebagai saksi korban KDRT di PN Denpasar. Jenis pengkajian yang digunakan adalah tipe pengkajian empiris. Hasil pembahasan dari pengkajian ini adalah faktor-faktor pembawa terjadinya KDRT lantaran kurangnya komunikasi antara suami dan istri pada keluarga yang ialah penentu keharmonisan keluarga dan penerapan perlindungan hukum akan perempuan sebagai saksi korban kekerasan di dalam KDRT di PN Denpasar pada kebenaran dilingkungan telah bergerak sebagian efektif semacam segala sesuatu yang diatur pada garis hukumnya. Sehingga petugas penegak hukum dapat menyelesaikan masalah KDRT dengan baik sehingga bisa menerima perlindungan bagi perempuan sebagai korban KDRT.
\end{abstract}

Kata Kunci: Perlindungan Aturan; Perempuan; KDRT.

\section{Pendahuluan}

Aturan kriminal selaku menyimpang suatu perangkat aturan lokal yang ialah barang pandangan individu yang terencana didapati bagi menjaga korban pada seluruh perlakuan kebengisan. Kebengisan aturan serupa perangkat bagi menjaga hak-hak individu dan rakyat amat signifikan dan terpaut melalui agenda untuk menjaga wanita dari tindak kebengisan (Wahid, 2001).
Kebengisan kepada wanita ialah salah satu sistem perlakuan yang bertolak belakang pada pondasi keindividuan. Itulah sebabnya perlakuan kebingasan pada wanita ialah salah satu perlakuan yang menyerang HAM sehingga di butuhkan suatu perangkat aturan lokal mengenai penghabisan kebengisan pada wanita di Indonesia.

Wanita ialah salah satu pribadi yang memikul tugas kembar pada aktivitas 
berindividu. Tugas perdana ialah pelanjut keterunan yang tidak mungkin diubah sang kaum pria. Tugas selanjutnya demi seorang istri yang ialah salah satu dalih panduan kenapa wanita butuh menerima perhatian yang utama untuk di lindungi dan di hormati kewenangan. ltulah sebabnya sehingga segala tindakan yang terpaut demi kebengisan pada wanita, termasuk perbuatan kebengisan menerima kepedulian pada aturan pidana. Kefaktaannya kewenangan wanita masih dianggap tidak sebanding oleh pria, wanita kadang kala selaku target kebengisan pada rumah tangga sebagaimana kebengisan fisik, psikis mencapai pada munculnya target jiwa. Sudut itu tercantum menandakan maka selagi wanita sedang di tempatkan pada kedudukan marginalisasi. (Chusari, 1997).

Perbuatan kebingasan pada wanita ialah bagian menurut fenomena sosial dan lain hal yang baru, sedangkan lokasi dan waktunya berbeda, namun prinsipnya dinilai sama. Di Indonesia perbuatan kebengisan pada wanita secara generik ialah perkara yang poligami di alami oleh banyak wanita, Terlebih bila perbuatan kebengisan termasuk berlaku pada rumah tangga, sebab perkara itu sedang dianggap kabur dan sedang dianggap sebagai perkara keluarga yang diselesaikan menurut kekeluargaan. Hal ini menampakkan masih berlimpahnya target wanita kebengisan pada rumah tangga merapatkan mulut dan mengemas perkara itu rapat-rapat.

Berdasarkan pada pemaparan latar belakang di atas dapat dirumuskan permasalahan yang pertama bagaimanakah faktor-faktor penyebab terjadinya kekerasan di dalam rumah tangga, yang kedua bagaimana perlindungan hukum terhadap perempuan sebagai saksi korban kekerasan di dalam rumah tangga di PN Denpasar.

\section{Metode}

Tipe riset studi yang dipakai pada riset studi ini tipe penelitian secara empiris dan menggunakan data primer atau lapangan. Data yang akan dipakai ialah data yang serentak diterima dari masyarakat. Pendekatan kasus berdasarkan penulisan skripsi ini ialah beserta memakai pendekatan yuridis empiris. Pendekatan dalam tipe riset studi ini dilakukan pada tipe riset studi lapangan yang akan di terima untuk menjawab persoalan dalam skripsi ini.

Pendekatan ini dapat dilakukan dengan memperhatikan kesesuaian pada UUD terhadap UU, maupun antara UU yang satu terhadap UU yang lainnya. Asal muasal materi aturan pada digunakan pada riset dalil-dalil normatif ini, bersumber pada riset kepustakaan pada bahanbahan aturan yakni pada pertama materi aturan primer, materi aturan yang didapat dari peraturan perUUan yang berlangsung. Perpu yang di teliti UU aturan Pidana yakni UUD 1945, KUHP, UU No. 23 Tahun 2004 Tentang KDRT, Kitab UU Hukum Perdata UU No. 13 Tahun 2006 Tentang Perlindungan Saksi dan Korban yang diperbaharui oleh Undang-undang No. 31 Tahun 2014. Dan yang kedua bahan aturan sekunder yakni bahan aturan sekunder yang di peroleh melalui peneltian kepustakaan, yang dapat berupa buku-buku, jurnal ilmiah, hasil penelitian ahli, media massa atau surat kabar dan juga sumber dari internet yang berkaitan dengan proses pembuktian di depan persidangan mengenai alat-alat bukti dan wawancara.

Mengenai teknik pengumpulan materi aturan riset studi aturan normatif, dengan materi -materi aturan yang diperoleh melalui kepustakaan, bahwa teknik penumpukkan bahan aturan dilaksanakan dengan cara: melakukan klasifikasi terhadap bahan-bahan hukum; melakukan pencatatan seluruh bahan hukum ; membaca; serta melakukan sistematika terhadap bahan-bahan hukum yang telah terkumpul, yang berkaitan dengan permasalaham dalam penelitian ilmiah proposal ini yang berkenaan dengan pelaksanaan mengenai alat-alat bukti dan deskriptif hasil wawancara.

Sedangkan analisis bahan hukum yang terkumpul dengan cara mencatat dan menganalisa. Analisa ialah fase selanjutnya untuk menggarap dampak penelitian pada suatu berita yang kemudian di jabarkan secara sistematis dengan menggunakan argumetasi hukum dan hasilnya kemudian di sajikan secara deskriptif analisis. Pelayanannya di lakukan melalui siasat deskriptif analisis ialah suatu siasat analisis materi aturan yang dilaksanakan dengan membangun kalimat secara sistematis sehingga diperoleh sebuah simpulan yang tepat dan benar secara logis dan ilmiah.

\section{Hasil dan Pembahasan}

\section{Perlindungan hukum kepada wanita yang menjadi korban KDRT di PN.}

UUP KDRT terlahir ketika melindungi para korban kebingasan pada rumah tangga. Hal ini ialah indikasi baik bagi mereka korban kebingasan pada rumah tangga sebab berhasil melakukan penagihan dan di lindungi selaku 
lembaga. Di keluarkannya banyak kesepakatan atau UU berperspektif gender buat melindungi wanita menurut pelanggaran HAM belum bisa sepenuhnya mengklaim wanita menurut pelanggaran HAM. (Aroma Elmina Martha, 2003;51).

Kehadiran UU No. 23 Tahun 2004 yang mengatur mengenai Penghapusan KDRT memang terasa sangat penting. Pembaharuan aturan yang lebih berpihak dalam kaum rentan atau group yang dianggap lemah khususnya wanita, sebagian banyak sangat dibutuhkan lantaran masih tak jarang terjadi tindak kebingasan yang terjadi pada lingkup rumah tangga.

Setelah pemerintah mengundangkan UU No. 23 Tahun 2004 Tentang Penghapusan KDRT pada Tanggal 22 September 2004, perlindungan hukum korban kebingasan wanita sudah diatur pada UU itu secara spesifik mengatur mengenai larangan melakukan kebingasan pada rumah tangga. Lingkup tempat tinggal sesuai menggunakan ketentuan Pasal 2 UU No. 23 Tahun 2004 meliputi :

"suami, istri, anak, orang - orang yang mempunyai hubungan keluarga karena hubungan darah, perkawinan, persusuan, pengasuhan, dan perwalian yang menetap dalam rumah tangga tersebut, serta orang yang bekerja membantu rumah tangga tersebut dan menetap dalam rumah tangga yang bersangkutan dalam jangka waktu tertentu".

Pada fenomena korban kebengasan pada rumah tangga mayoritas ialah wanita atau istri. Itulah sebabnya eksistensi UU No. 23 Tahun 2004 tersirat pada rumusannya lebih menonjol dalam perlindungan pada istri maupun wanita pada kehidupan rumah tangga atau perkawinan. (Manan, 1992).

Ancaman kebengisan yang terjadi pada rumah tangga yang kerap kali dilakukan para group keluarganya sendiri susah bisa di tinjau oleh orang luar misalnya KDRT yang dirasakan oleh istri, ibu, anak, pembantu wanita (Astuti , 2002). Korban misalnya kerap kali berani mengadu, di antaranya lantaran jalinan kekeluargaan, nilai sosial tertentu, nama baik (prestise) keluarga juga dirinya atau korban merasa risih apabila pelaku melancarkan balas dendam. Kerumitan misalnya inilah yang diperkirakan akan timbul bila korban melapor. Para pelaku dan korban menurut suatu viktimisasi kerap kali pernah bekerja sama atau saling mengenal satu sama lainnya terlebih dahulu.
Hambatan dalam memberikan perlindungan hukum kepada wanita yang selaku korban KDRT.

Berdasarkan laporan tahunan komisi nasional wanita Tahun 2010 meskipun sudah terdapat perkembangan yang baik pada jumlah anggaran dan forum yang penanganan korban dan koordinasi lintas instansi, dan serta kualitas pelayanan dan penanganan sudah memenuhi kebutuhan korban KDRT atas kebenaran, keadilan dan pemulihan baik yang dialami korban dan pelapor. Hambatannya terdapat pada macam lapisan, termasuk diantara ialah kapasitas dari forum-forum fasilitas.

Hasil wawancara pada hari kamis tanggal 04 maret 2021 pukul 13:00 WITA, yang menjadi hambatan untuk perlindungan hukum itu di lihat dari pasal- pasal pemidanaan, apabila di lakukan oleh seorang suami terhadap istri itu merupakan delik aduan begitu ada klausul di dalam pasal-pasal pemidanaan UUPKDRT sehingga apabila polisi di adukan KDRT ini antara suami dan istri apakah bisa berdamai kembali karena merupakan delik aduan dan bisa di cabut.

Ini merupakan kendala penegakan hukumnya karena UU tersebut apabila melakukan tindak kebingasan yang tidak mengakibatkan meninggal, cacat tetap seperti kasus kaki terpotong dan meyebabkan sakit yang sampai tidak bisa melakukan pekerjaan itu semua adalah delik aduan. Terlebih lagi di lakukan oleh suami terhadap istri di samping itu juga di lihat dari asas tujuan dari undangundang ini :

\section{Mencegah tindakan KDRT.}

\section{Menindak pelakunya.}

3. Mewujudkan rumah tangga yang harmonis. (Bambang, 2012).

Tujuan dari UU ini ada bukan untuk memberantakan rumah tangga tetapi untuk membuat keharmonisan di dalam rumah tangga dan ini merupakan pegangan dari pada penegak hukum baik itu polisi, maupun kejaksaan karena hanya delik aduan maka di usahakan agar bisa rujuk kembali dan di damaikan. Delik aduan laporan itu bisa di cabut atau aduan itu bisa di cabut itu sebabnya kenapa lemah di penegakkan hukumnya.

Tetapi terkadang bagi korban KDRT kebanyakan memilih perdata dari pada di laporkannya KDRT juga tidak akan di hukum terlalu berat dan di usulkan untuk berdamai lebih baik di putuskanlah perkawinan tersebut 
dan di gugat perceraian karena di sanalah arah dari perdata.

\section{Simpulan}

Berdasarkan pada pengkajian tentang perseteruan yang di bahas pada penelitian ini pada bab sebelumnya, maka bisa ditarik kesimpulan sebagai berikut :

Faktor-faktor penyebab terjadinya KDRT di latar belakangi pada kurangnya komunikasi antara suami dan istri pada keluarga yang ialah penentu keharmonisan keluarga, terdapat keharmonisan pada rumah tangga, kesalahan istri, ketidak mampuan secara ekonomi, adanya perselingkuhan yang dilakukan para suami dan imbas minuman keras serta imbas adanya kawin paksa berdasarkan pihak keluarga.

Pelaksanaan proteksi hukum terhadap wanita sebagai saksi korban KDRT di PN Denpasar pada fenomena dilapangan belum berjalan secara efektif contohnya apa yang diatur pada ketentuan hukumnya. Hal ini disebabkan pada faktor budaya anggaran yang lemah dan wahana prasarana dan anggaran aturan belum memadai.

\section{Daftar Pustaka}

Astuti, P. (2002). Kemandirian dan Kekerasan Terhadap Istri. Bulletin psikologi.

Bambang. (2012). Viktimologi Perlindungan Korban Dan Saksi. Jakarta: Sinar Grafika.

Chusari, A. (1997). Kekerasan Terhadap Istri dan Ketidakadilan Gender. Jakarta: Paradigma.

Manan, B. (1992) Dasar-dasar perundangundangan Indonesia. Jakarta: IndHillCo

Martha, A. E. (2003). Perempuan, Kekerasan, dan Hukum. Yogyakarta: Penerbit UII Press.

Wahid, A. (2001). Perlindungan Terhadap Korban Kekerasan Seksual (Advokasi Atas Hak Asasi Perempuan). Bandung: Refika Aditama. 